\title{
Petrogenetic and tectonic aspects of collisional granitoids from the Sanandaj-Sirjan Belt of Iran
}

\author{
Robab Hajialioghli*, Mohssen Moazzen \\ Department of Geology, University of Tabriz, Tabriz, Iran
}

\begin{abstract}
The Sanandaj-Sirjan granitoids (SSG) in western Iran are composed mainly of granite, granodiorite and tonalite. Chemically the rocks are peraluminous and metaluminous, and show S-and I-type characteristics. The oval shape of the plutons, with large axes parallel to the Zagros main trend, along with deformational textures and structures, the existence of aluminous minerals such as andalusite, garnet and sillimanite as well as micaceous enclaves and geochemical features, all support generation of these rocks by partial melting of heterogeneous source materials in a continental collision setting, corresponding to the Zagros Orogen.
\end{abstract}

Key words: collisional setting, partial melting, granitoids, Neotethys, Sanandaj-Sirjan, Iran

\section{Introduction}

The Zagros Ocean, as a branch of Neotethys between the Central Iranian Block and the Arabian Plate closed due to subduction beneath the Central Iranian Block; the Zagros Mountains were formed in the process. Figure 1 shows the collisional suture of Neotethys in the Middle East and the location of Iran. Subduction of Neotethys is still active in the Makran in southeastern Iran (Farhoudi and Karig 1977; McCall 1997). The accurate timing of the final collision between the Arabian Plate and the Iranian Block, and of the associated magmatic activity, are controversial. Berberian and King (1981) and Alavi (1994) advanced a late Cretaceous age for collision along the Zagros Suture. Others describe a Cenozoic continental collision (e.g. Eocene: Berberian et al. 1982; Braud 1987;

Addresses: R. Hajialioghli, M. Moazzen: University of Tabriz, 51664, Tabriz, Iran *Corresponding author e-mail: hajialioghli@tabrizu.ac.ir, Phone: +98 4113392623

Received: November 28, 2011; accepted: May 30, 2012 


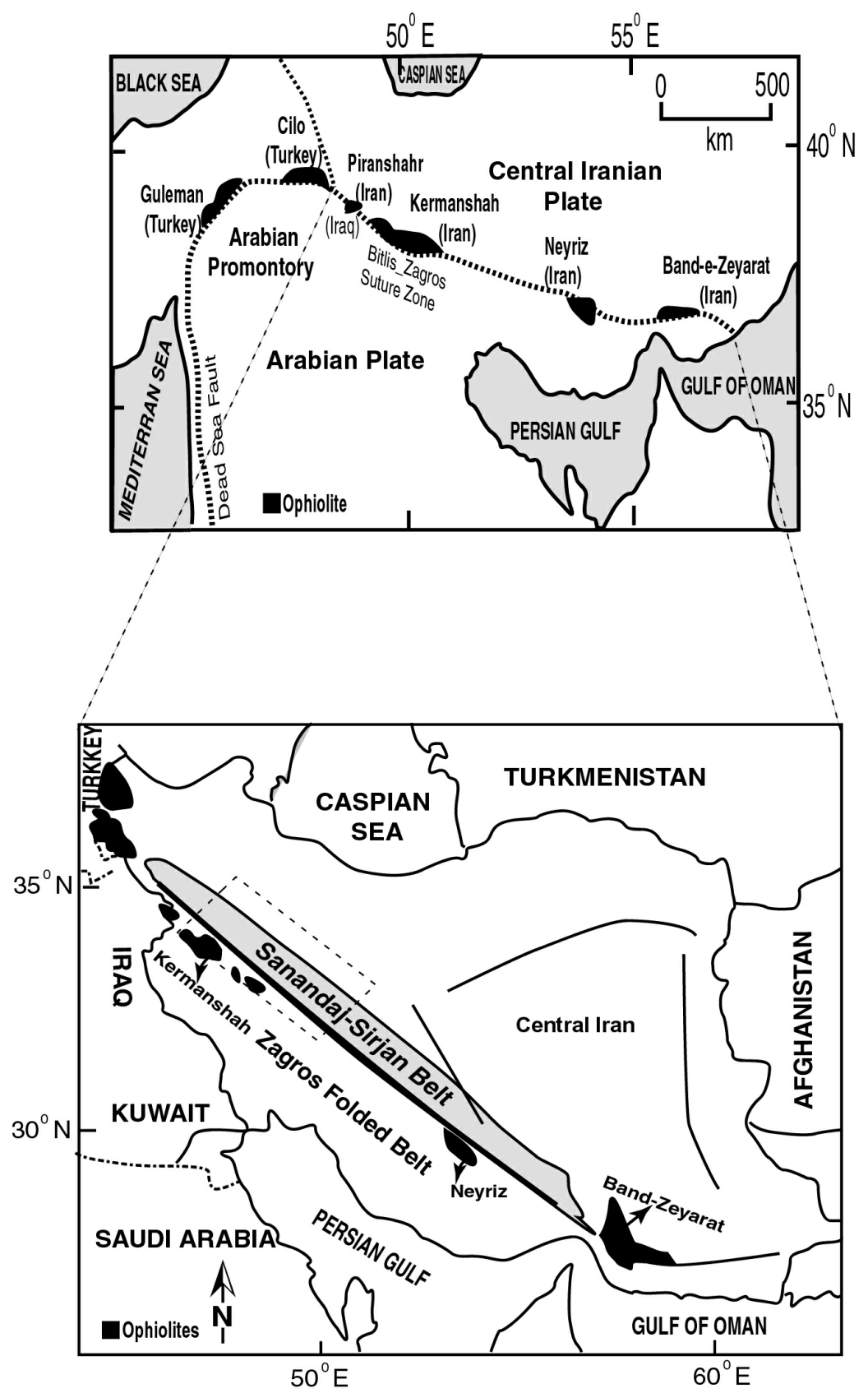

Fig. 1

(a) Collisional suture of Neotethys at the site of collision of the Central Iran Block and Arabian Plate. Black patches show remnants of Neotethys ophiolites. (b) Sanandaj-Sirjan metamorphic belt of Iran with ophiolitic rocks 
Sengör et al. 1988; 1993; Sengör and Natal'in 1996; Mohajjel et al. 2003; Ghasemi and Talbot 2006; Oligocene: Agard et al. 2005; and Miocene: Jackson et al. 1995).

The Sanandaj-Sirjan Zone is part of the Neotethys orogen, which has recorded the metamorphic affects in relation to opening, subduction and collisional events. Metamorphism and deformation in the Sanandaj-Sirjan Zone, along with intrusion of numerous granitoids, are the result of subduction and subsequent closing of Neotethys (Fig. 2). Granitoids in the Sanandaj-Sirjan Zone are composite plutons composed of rocks of different mineralogical and chemical compositions. The variation of composition of the granitoids is probably due to heterogenic sources, which are considered in this contribution.

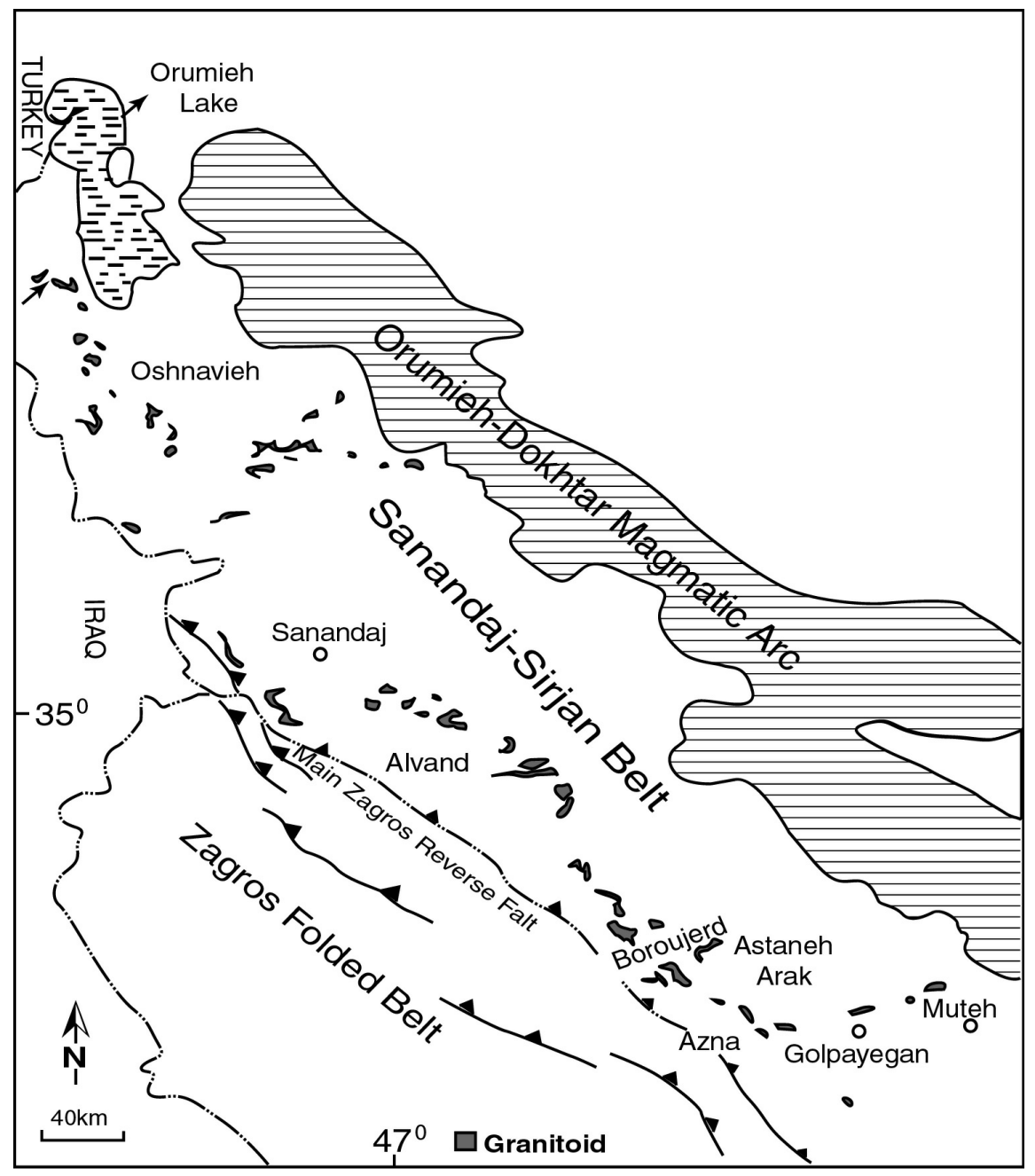

Fig. 2

Collisional granitoids of the Sanandaj-Sirjan Zone with a NW-SE emplacement trend (in grey) 
Petrographic and geochemical characteristics of the Boroujerd, Azna, Astaneh, Arak, Alvand, Golpayegan and Oshnavieh granitoids within the Sanandaj-Sirjan Zone are studied, and the tectonic setting and petrogenetic origin of these rocks are discussed.

\section{Field relationships of the Sanandaj-Sirjan granitoids}

The NW-SE trend Sanandaj-Sirjan Zone, with a length of $\sim 1500 \mathrm{~km}$ and a width of $\sim 200 \mathrm{~km}$, is the metamorphic zone of the Zagros Mountains. This zone is one of the most active structural units in Iran and has experienced different metamorphic and magmatic events from the Precambrian to the Cenozoic. The stratigraphic features of the Sanandaj-Sirjan Zone are similar to those of the Central Iran Zone, but its trend and structural features are similar to those of the Zagros Orogen (Alavi 1994). Most of the rocks are exposed in the Sanandaj-Sirjan Zone and belong to the Mesozoic. The Paleozoic rocks are rarely exposed in the NW part (from Golpayegan to Orumieh), while they are abundant in the southeastern part of the Sanandaj-Sirjan Zone (Berberian 1977; Sabzehi 1992). Metapelitic and meta-semipelitic rocks known as Hamadan phyllites are the result of regional metamorphism of Jurassic shales under greenschist facies conditions. Intrusion of granitoids into the Hamadan phyllites caused contact metamorphism (e.g. Isfahani and Sharifi 1999; Moazzen et al. 2002; Moazzen et al. 2004). The emplacement of the granitoids follows the main trend of the Zagros suture zone. Most of the granitoid bodies are oval in shape and the long axes are parallel to the main trend of the Sanandaj-Sirjan Zone. Some felsic dykes with aplitic and pegmatitic composition have cut the granitoids with an overall trend of NW-SE. Also, rounded enclaves at $\mathrm{mm}$ to $\mathrm{cm}$ scale are seen in these granitoids. The enclaves can be divided into two main groups: (i) microgranular mafic and felsic enclaves, which are fragments of chilled margins of the plutons, and (ii) micaceous enclaves with minerals such as sillimanite, andalusite and garnet, which are fragments of metamorphic rocks (Moazzen et al. 2004). The latter enclaves indicate a possible palingenetic origin for the studied granitoids.

\section{Petrography}

Granitoids in the Sanandaj-Sirjan Zone can be divided into three main groups based on their mineralogy: granites, granodiorites and tonalites. Mineralogical and petrographic features of the Sanandaj-Sirjan granitoids (SSG) are summarized in Table 1.

Granites: Granites make up the main granitoid types in the Sanandaj-Sirjan Zone. These rocks are composed mainly of quartz (35-40 modal \%), orthoclase $(\sim 30$ modal $\%)$, plagioclase ( $\sim 20$ modal $\%)$ and biotite (5-10 modal \%). Pale color, low biotite content and the presence of perthitic, micrographic and/or granophyric textures are the dominant features. Preferred orientation of mica 
Table 1

Mineralogical features of the SSG

\begin{tabular}{|c|c|c|c|}
\hline Granitoid & Minerals & Enclaves & Locality \\
\hline Alvand & $\begin{array}{l}\text { Qtz+Kfs+PI+Bt+Ms+Grtt(And, } \\
\text { Tur, Crd, Sil, Hbl) }\end{array}$ & $\begin{array}{l}\text { Micaceous, felsic } \\
\text { microgranular, relict minerals } \\
\text { (And, Sil, Grt) }\end{array}$ & $\begin{array}{l}N 48^{\circ} 35^{\prime}-48^{\circ} 13^{\prime} \\
E 34^{\circ} 52^{\prime}-34^{\circ} 30^{\prime}\end{array}$ \\
\hline $\begin{array}{l}\text { Boroujerd } \\
\text { (Astaneh, } \\
\text { Azna, SW } \\
\text { Arak) }\end{array}$ & $\begin{array}{l}\text { Qtz+Kfs+PI+Bt+Ms } \pm(C r d, \text { Sil, } \\
\text { Grt, Hbl, And, Tur })\end{array}$ & $\begin{array}{l}\text { Metamorphic enclaves } \\
\text { Micaceous } \\
\text { Felsic microgranular }\end{array}$ & $\begin{array}{l}N 49^{\circ} 22^{\prime}-49^{\circ}-00^{\prime} \\
E 33^{\circ} 38^{\prime}-33^{\circ} 54^{\prime}\end{array}$ \\
\hline Golpayegan & $\begin{array}{l}\text { Qtz+Kfs+Pl+Bt+Ms } \pm(C r d, S i l, G r t \\
\text { Hbl, And,Tur Zrn, Ap) }\end{array}$ & $\begin{array}{l}\text { Relict minerals (And, Sil, Grt) } \\
\text { Micaceous } \\
\text { Felsic microgranular }\end{array}$ & $\begin{array}{l}\text { N49 } 22^{\circ}-49^{\circ}-00^{\prime} \\
E 33^{\circ} 38^{\prime}-33^{\circ} 54^{\prime}\end{array}$ \\
\hline Oshnavieh & $\begin{array}{l}\text { Qtz+Kfs+PI+Bt+Ms } \pm(G r t, T t n, \\
z r n, \text { Tur, IIm) }\end{array}$ & $\begin{array}{l}\text { Metamorphic enclaves } \\
\text { Micaceous } \\
\text { Felsic and mafic } \\
\text { microgranular }\end{array}$ & $\begin{array}{l}N 45^{\circ} 24^{\prime}-45^{\circ}-00^{\prime} \\
\text { E3 } 37^{\circ} 16^{\prime}-37^{\circ} 05^{\prime}\end{array}$ \\
\hline
\end{tabular}

Mineral name abbreviations are from Kretz (1983)

minerals and undulating extinction in feldspars and quartz, along with kink structure in the minerals, all indicate influence of tectonic strains during or after emplacement. Minor minerals in the granites are muscovite, garnet, sillimanite, andalusite and cordierite of both magmatic and metamorphic (relict) origins. Accessory phases are apatite, zircon, alanite and iron oxides. Sericite, kaolinite and chlorite are alteration products.

Granodiorites: Granodiorites are darker in color than granites and have a higher modal proportion of plagioclase and biotite and rare amphiboles. The major minerals in these rocks are plagioclase $(\sim 40$ modal $\%)$, quartz $(\sim 20$ modal $\%)$, orthoclase (15-20 modal\%) and biotite (10-15 modal\%). The minor and accessory phases are similar to those in the granites except for minor amounts of amphiboles, present in some samples.

Tonalites: Tonalites have the least exposure area and are mainly composed of plagioclase (65-75 modal \%) and quartz (20-30 modal \%). Orthoclase, zircon, apatite, tourmaline and iron oxides occur as minor phases.

\section{Analytical setting}

Numerous samples from SSG are analyzed by different authors, mainly using the XRF method. Representative data, taken from the literature, are provided in Table 2 along with CIPW normative minerals. The $\mathrm{Fe}_{2} \mathrm{O}_{3}$ and $\mathrm{FeO}$ content of the rocks are calculated according to the Irvine and Baragar (1971) method, and corrections are made following LeMaitre (1976). 


\section{Discussion and conclusions}

The $\mathrm{SiO}_{2}$ contents of the granitoids are between $64 \%$ and $78 \%$. The samples plot in the granite, granodiorite, tonalite and quartz monzonite fields in the $\mathrm{Na}_{2} \mathrm{O}+\mathrm{K}_{2} \mathrm{O}$ vs. $\mathrm{SiO}_{2}$ diagram of Middlemost (1994) and in the normative diagram of O'Connor (1965) (Figs 3-4). Almost all samples show sub-alkalic characteristics. Some samples plot in the alkaline field according to the Miyashiro (1978) definition (Fig. 3). In the $\mathrm{K}_{2} \mathrm{O} / \mathrm{SiO}_{2}$ diagram of Peccerillo and Taylor (1976), most rocks have mainly high $\mathrm{K}$ content (Fig. 5). Samples from the Golpayegan granitoid plot in the low to medium $\mathrm{K}$ field. Most of the rocks have ASI $>1$ (molar $\left.\mathrm{ASI}=\mathrm{Al}_{2} \mathrm{O}_{3} / \mathrm{CaO}+\mathrm{Na}_{2} \mathrm{O}+\mathrm{K}_{2} \mathrm{O}\right)$, plotting in the peraluminous field, while some others show ASI $<1$ and metaluminous nature (Fig. 6). Peraluminous granitoids with normative corundum greater than $1 \%$ (69 samples show $\sim 2.7$ normative $\%$ corundum) are S-type. Metaluminous granitoids with less than 1 normative $\%$ corundum and $\sim 1.1$ normative \% diopside (28 of 106 samples show $\sim 1.1$ normative $\%$ diopside) are I-type (Table 2). Plotting the samples in $[\mathrm{FeO} /(\mathrm{FeO}+\mathrm{MgO})] / \mathrm{SiO}_{2}$ and $\left(\mathrm{Na}_{2} \mathrm{O}+\mathrm{K}_{2} \mathrm{O}+\mathrm{CaO}\right) / \mathrm{SiO}_{2}$ diagrams (Frost et al. 2001) confirm the $S$ and I-types for these rocks (Fig. 7a-b).

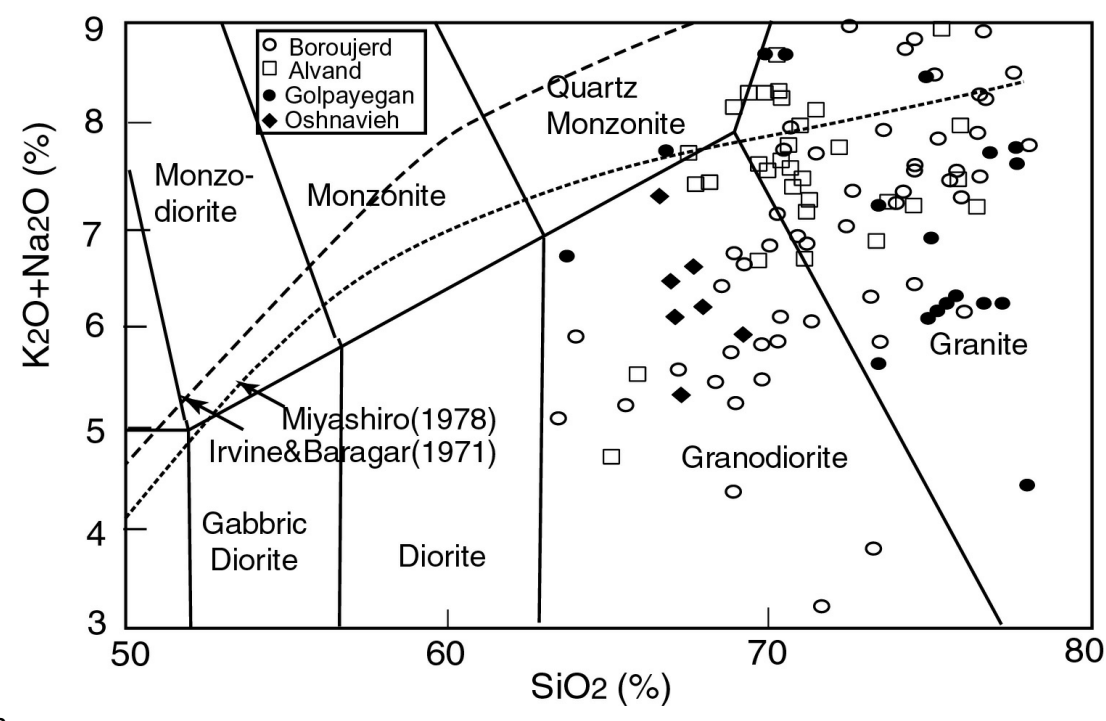

Fig. 3

Classification of the SSG in total alkalis vs. $\mathrm{SiO}_{2}$ diagram from Middlemost (1994). The boundaries separating alkaline and sub-alkaline rocks are from Miyashiro (1978) and Irvine and Baragar (1971)

In the Q-Ab-Or triangular diagram (Fig. 8), most of the samples (except for some from the Golpayegan granitoid) plot in the eutectic and minimum melting temperature (James and Hamilton 1969).

In order to determine the tectonic setting of the studied granitoids, both major and trace elements are used. Samples plot in the island arc granite (IAG), volcanic 
Fig. 4

Or-Ab-An diagram of O'Connor (1965) for classification of the SSG. Most of the samples plot in the granite and quartz monzonite sectors of this diagram

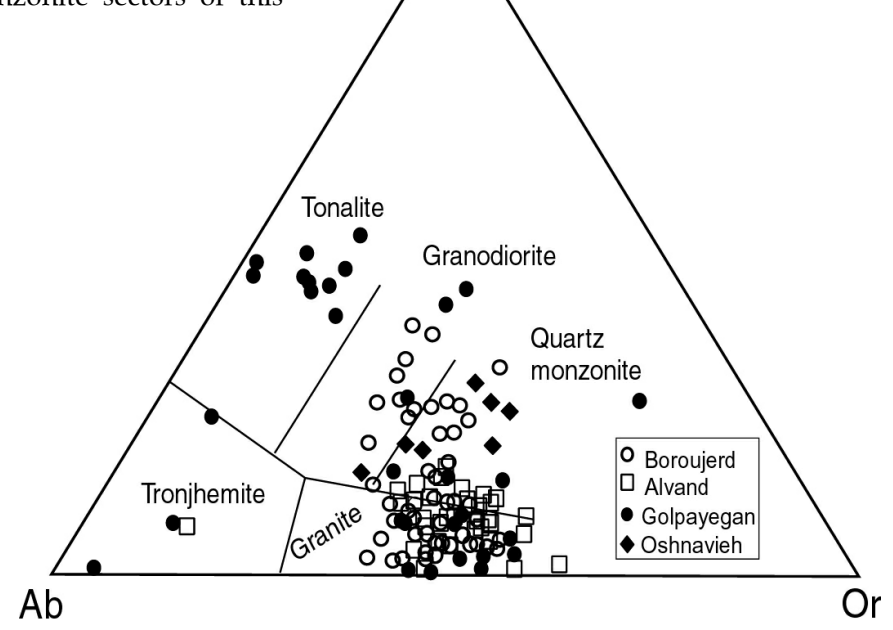

arc granite (VAG) and continental collision granite (CCG) fields in an $\left[\mathrm{FeO} /(\mathrm{FeO}+\mathrm{MgO}) / \mathrm{SiO}_{2}\right]$ diagram after Pearce et al. (1984) (Fig. 9). Y-SiO 2 and $\mathrm{Rb}-$ $\mathrm{SiO}_{2}$ diagrams (after Pearce et al. 1984) show syn-collision and volcanic arc characteristics for the granitoids (Fig. 9). The collisional and volcanic arc settings correspond to $\mathrm{S}$ and I-type granitoids, respectively.

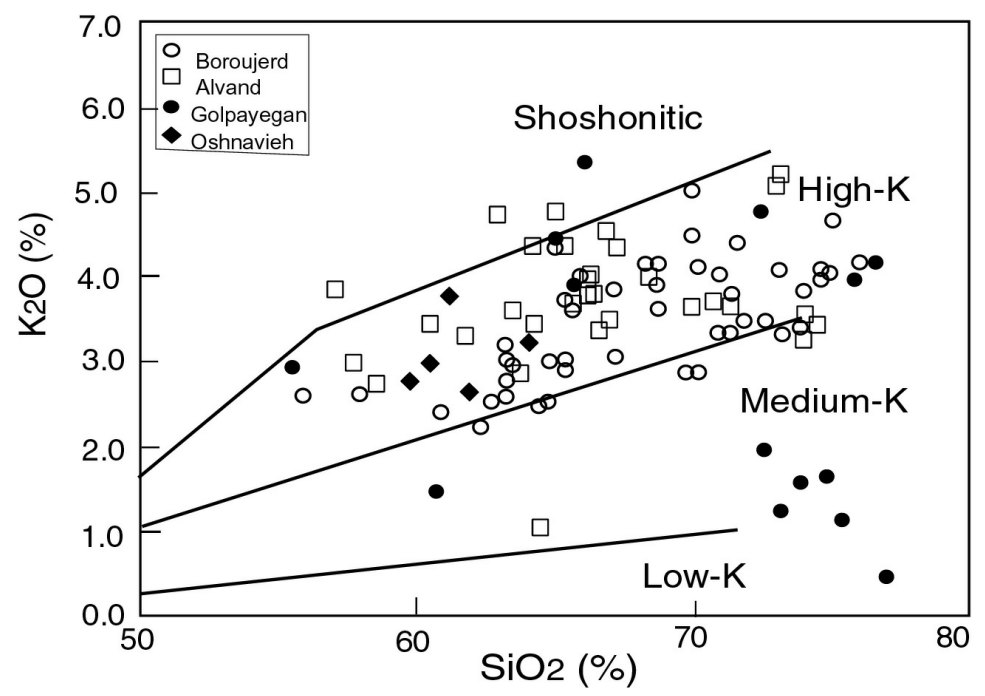

Fig. 5

The SSG samples on a $\mathrm{K}_{2} \mathrm{O}$ vs. $\mathrm{SiO}_{2}$ diagram of Rickwood (1989). Samples show high-K characteristics. Medium to low-K features of some samples can be attributed to the metasomatic processes 


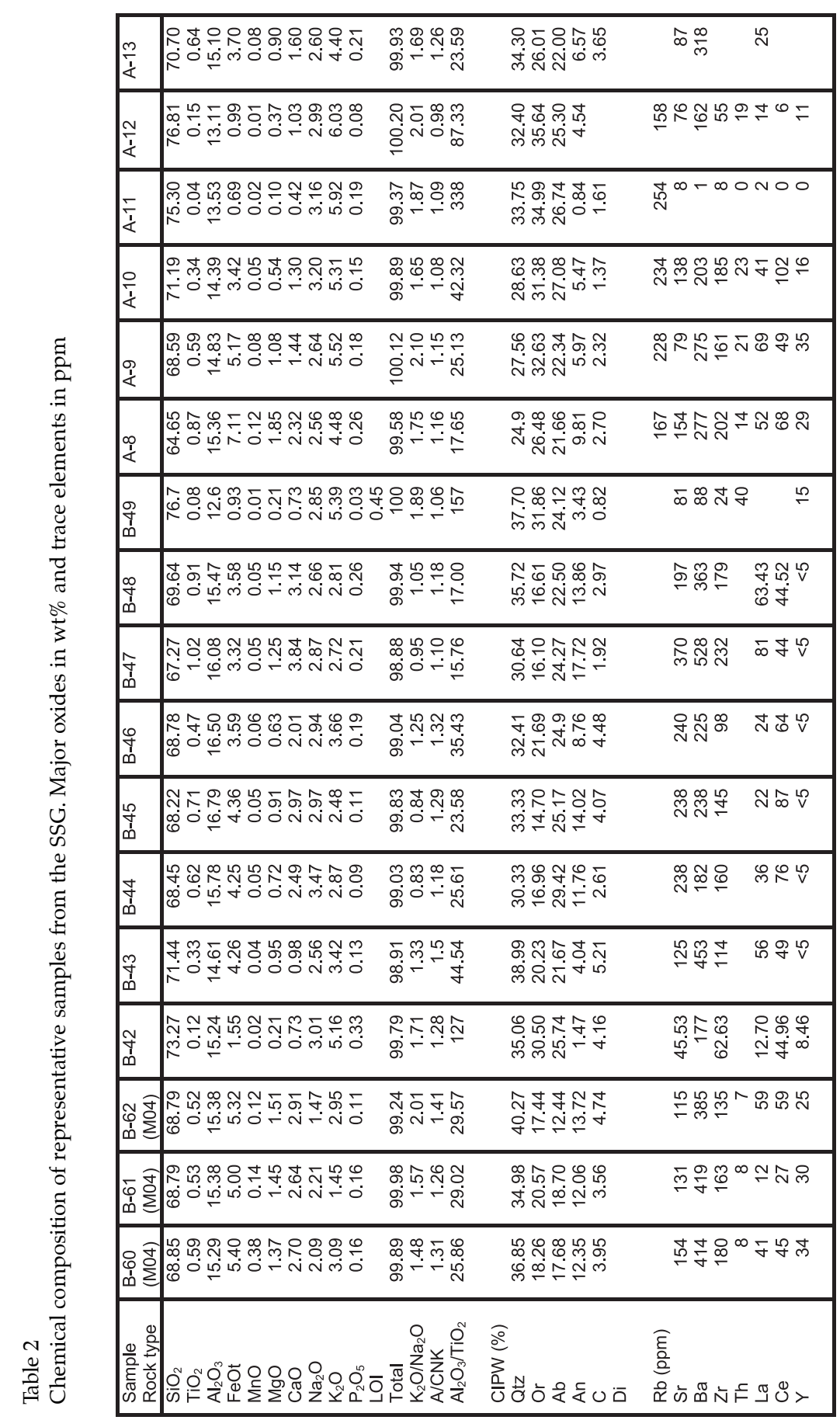

Central European Geology 55, 2012 
Petrogenetic and tectonic aspects of collisional granitoids from the Sanandaj-Sirjan Belt of Iran 93

\begin{tabular}{|c|c|c|c|c|}
\hline$\frac{5}{\text { | }}$ & 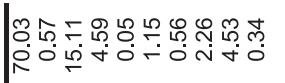 & 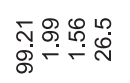 & 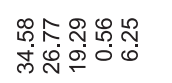 & 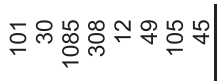 \\
\hline 立 & 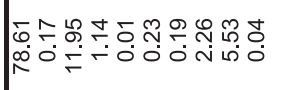 & m & 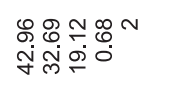 & 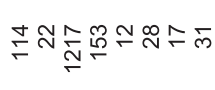 \\
\hline 文 & 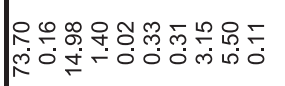 & 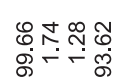 & 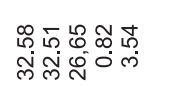 & 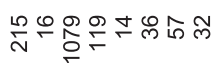 \\
\hline | & 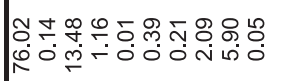 & 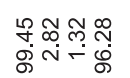 & 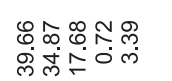 & 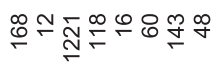 \\
\hline |ร & 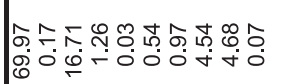 & 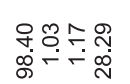 & 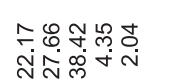 & 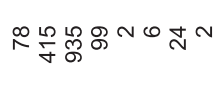 \\
\hline$\frac{c}{\bar{\delta}}$ & 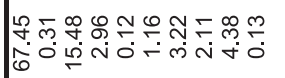 & 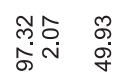 & 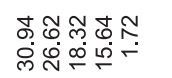 & 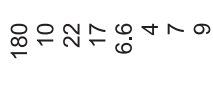 \\
\hline$\frac{c}{\phi}$ & 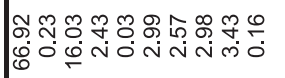 & $\begin{array}{l}\text { 늉 } \\
\stackrel{\circ}{\circ}\end{array}$ & 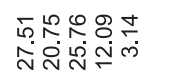 & 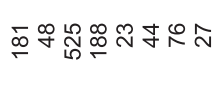 \\
\hline$\frac{\Gamma}{\delta}$ & 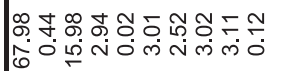 & 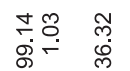 & 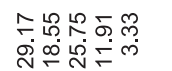 & 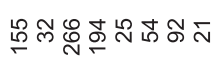 \\
\hline कू & 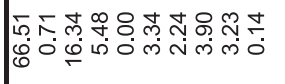 & 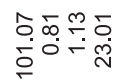 & 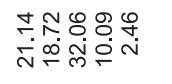 & 논 \\
\hline$\frac{c}{\phi o n}$ & 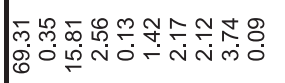 & 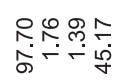 & 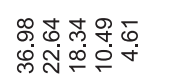 & № \\
\hline $\mid$ & 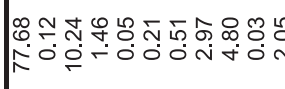 & ن & 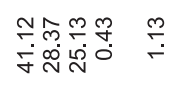 & 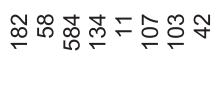 \\
\hline $\mid \begin{array}{ll}1 \\
0 \\
0 \\
0 \\
0\end{array}$ & 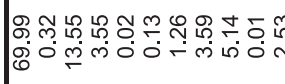 & 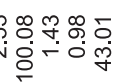 & 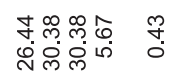 & 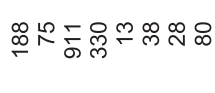 \\
\hline$\circ$ & 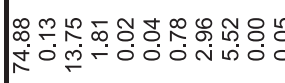 & 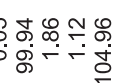 & 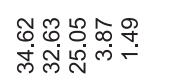 & స్ల N \\
\hline 票 & 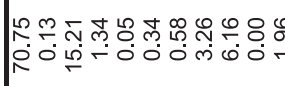 & 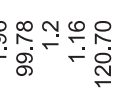 & 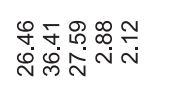 & 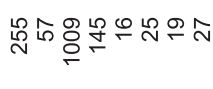 \\
\hline $\begin{array}{l}\infty \\
0 \\
0 \\
0 \\
0\end{array}$ & 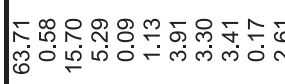 & 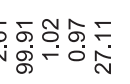 & 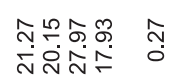 & 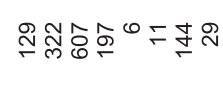 \\
\hline$\frac{\infty}{\frac{1}{\alpha}}$ & 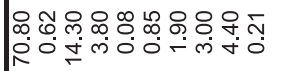 & 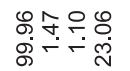 & 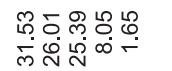 & 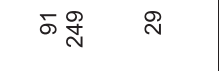 \\
\hline$\frac{1}{4}$ & 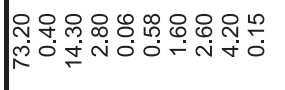 & 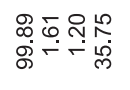 & 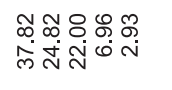 & గై $\mathbb{N}$ \\
\hline 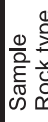 & 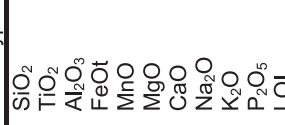 & 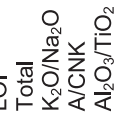 & 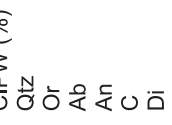 & $\grave{N} \vDash \circlearrowleft \circlearrowleft$ \\
\hline
\end{tabular}




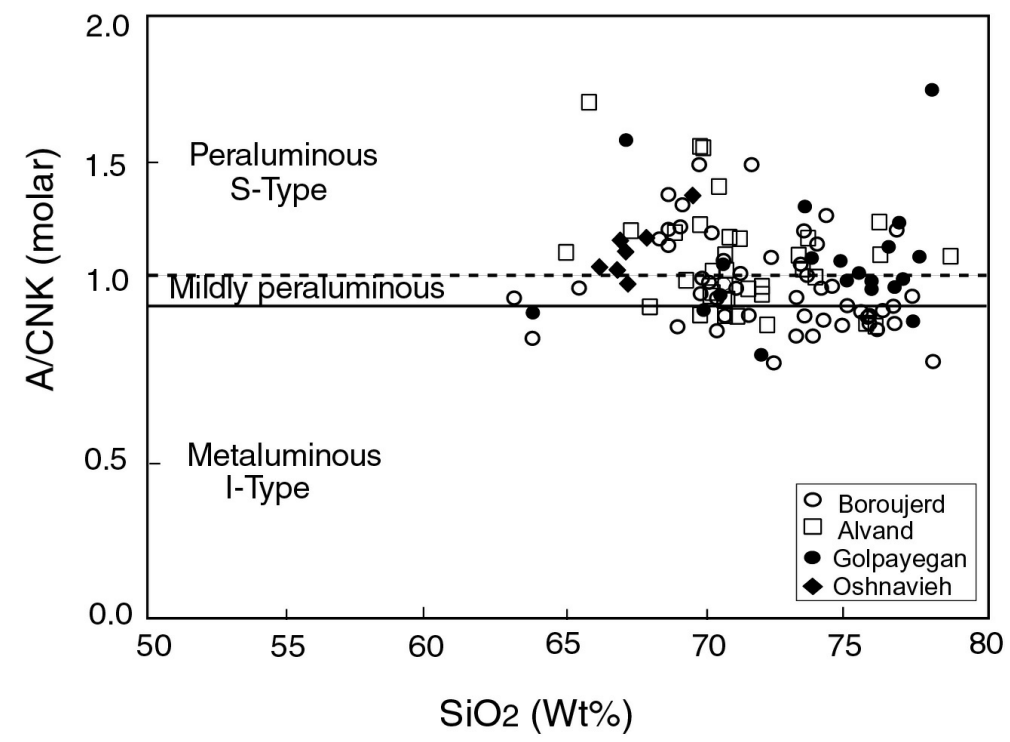

Fig. 6

Peraluminous to metaluminous nature of the SSG is clear in diagram of $\mathrm{Al} /(\mathrm{Ca}+\mathrm{Na}+\mathrm{K}) \mathrm{vs} . \mathrm{SiO}_{2}$ of Chappell and White (1992). Most of the samples are peraluminous

\section{Variation of major and trace elements}

Variation diagrams for the studied granitoids are illustrated in Fig. 10, where all oxides and elements are plotted against $\mathrm{SiO}_{2}$. The negative trends of $\mathrm{TiO}_{2}$, $\mathrm{FeO}$ (total), $\mathrm{MgO}$ and $\mathrm{Al}_{2} \mathrm{O}_{3}$ reflect the lower abundance of ferromagnesian minerals such as biotite and hornblende in the rocks, with a higher $\mathrm{SiO}_{2}$. $\mathrm{Al}_{2} \mathrm{O}_{3} / \mathrm{TiO}_{2}$ ratio for most of the samples $\left(\mathrm{Al}_{2} \mathrm{O}_{3} / \mathrm{TiO}_{2}=14-75\right.$ for 80 samples $)$ (Table 2), along with $\mathrm{Sr}, \mathrm{Ba}$ and $\mathrm{Rb}$ contents of the rocks, reflect the modal
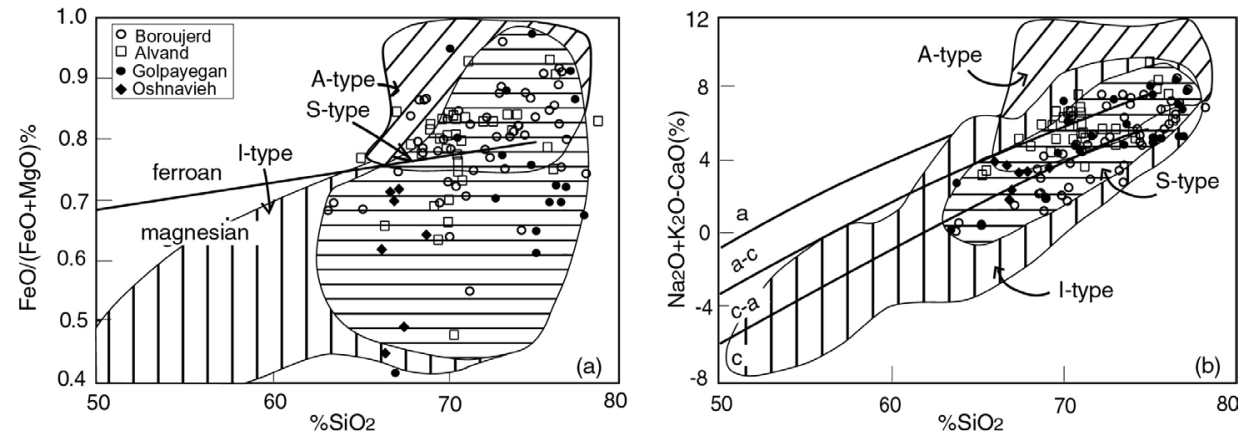

Fig. 7

(a) $(\mathrm{FeO} / \mathrm{FeO}+\mathrm{MgO}) \%$ vs. $\mathrm{SiO}_{2}$ and (b) $\left(\mathrm{Na}_{2} \mathrm{O}+\mathrm{K}_{2} \mathrm{O}-\mathrm{CaO}\right) \%$ vs. $\mathrm{SiO}_{2}$ diagrams of Frost et al. (2001) indicate $\mathrm{S}$ - and I-types for the studied granitoids. Most of the samples plot in the S-type field 


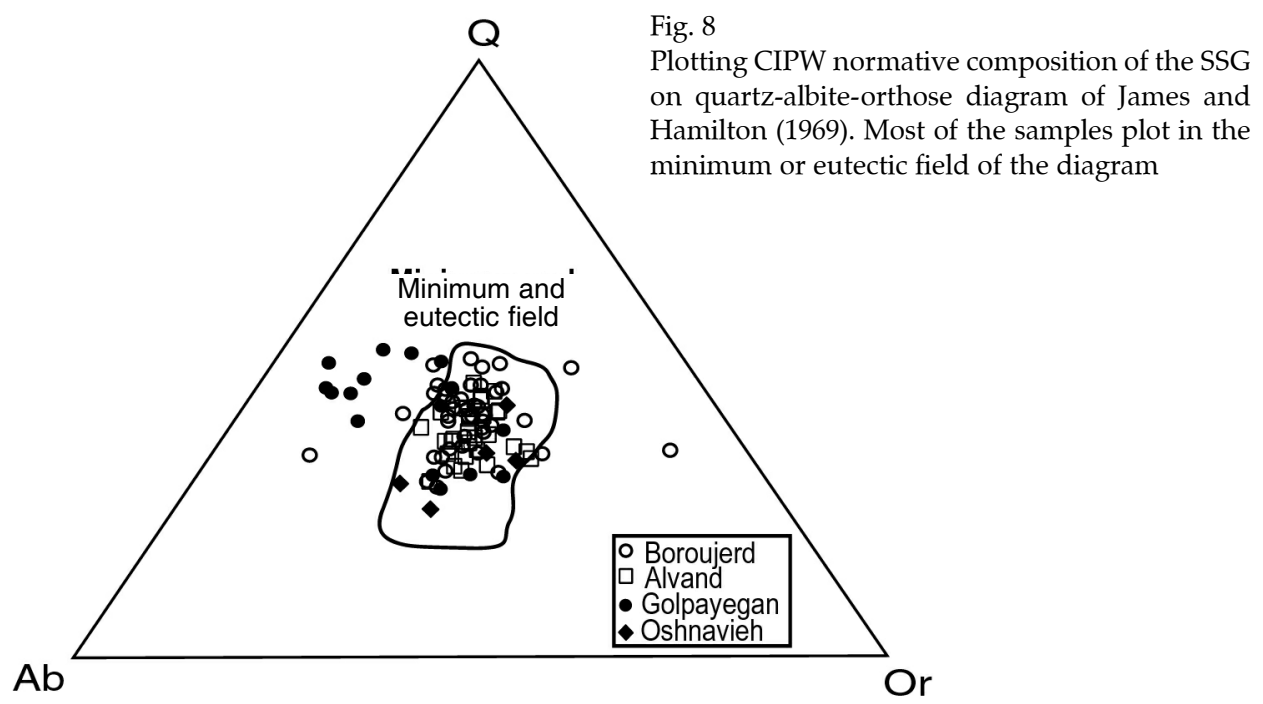

feldspars and micas (Harris et al. 1986). The wide range of $\mathrm{Na}_{2} \mathrm{O}$ content is probably due to the contribution of different amounts of plagioclase in the melting process of source materials. The negative trend for $\mathrm{CaO}$ and $\mathrm{Sr}$ shows an early Ca-rich plagioclase crystallization in these rocks. Also, high $\mathrm{CaO}$ content can be attributed to the existence of calcic amphiboles in some granodiorites. The high $\mathrm{K}_{2} \mathrm{O}$ content in the granites and high $\mathrm{Rb}$ content in the granodiorites can be related to high $\mathrm{K}$-feldspar and biotite in these rocks, respectively (except for Golpayegan samples). The varying $\mathrm{Zr}$ and $\mathrm{P}_{2} \mathrm{O}_{5}$ contents in the rocks are probably due to different modal proportion of apatite and zircon in the analyzed samples.

\section{The behavior of the incompatible trace elements}

The behavior of the incompatible trace elements was studied for selected elements using a spider diagram (Fig. 11). The elements are normalized to primary mantle. The normalization factors are from Sun and McDonough (1989). The distribution pattern for trace elements may suggest similar sources for SSG. These patterns are comparable to those for the collision granites of Halatu in the Himalaya (Chen et al. 2000), which are of crustal origin. The minor differences among the patterns for LILE can be explained by possible late alteration, while differences in more compatible elements may reflect heterogeneity of the source materials.

$\mathrm{Th}, \mathrm{Rb}, \mathrm{K}, \mathrm{HFSE}, \mathrm{Y}$ and $\mathrm{Zr}$ show enriched amounts relative to primary mantle, while $\mathrm{Ba}$ and $\mathrm{Sr}$ show lesser relative enrichments. Relatively low amounts of $\mathrm{Y}$ and $\mathrm{Zr}$ and enrichment of $\mathrm{Ba}, \mathrm{Rb}, \mathrm{Ce}$ and $\mathrm{Th}$ are consistent with collisional granitoids with crustal contribution (Harris and Inger 1992; Wang et al. 2001). 


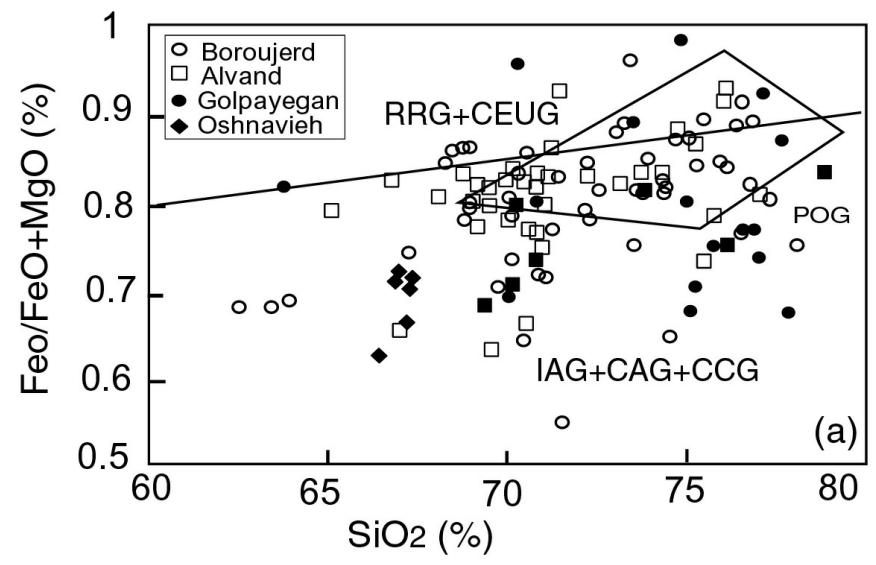

Fig. 9

The SSG show continenta collision granitoid (CCG) and volcanic arc granitoid (VAG) tectonomagmatic settings on $\mathrm{FeO} /(\mathrm{FeO}$ $+\mathrm{MgO})$ vs. $\mathrm{SiO}_{2}, \mathrm{Y}$ vs. $\mathrm{SiO}_{2}$ and $\mathrm{Rb}$ vs.SiO diagrams of Pearce et al (1984). CCG and VAG are related to pelitic and basic origin for the rocks, respectively
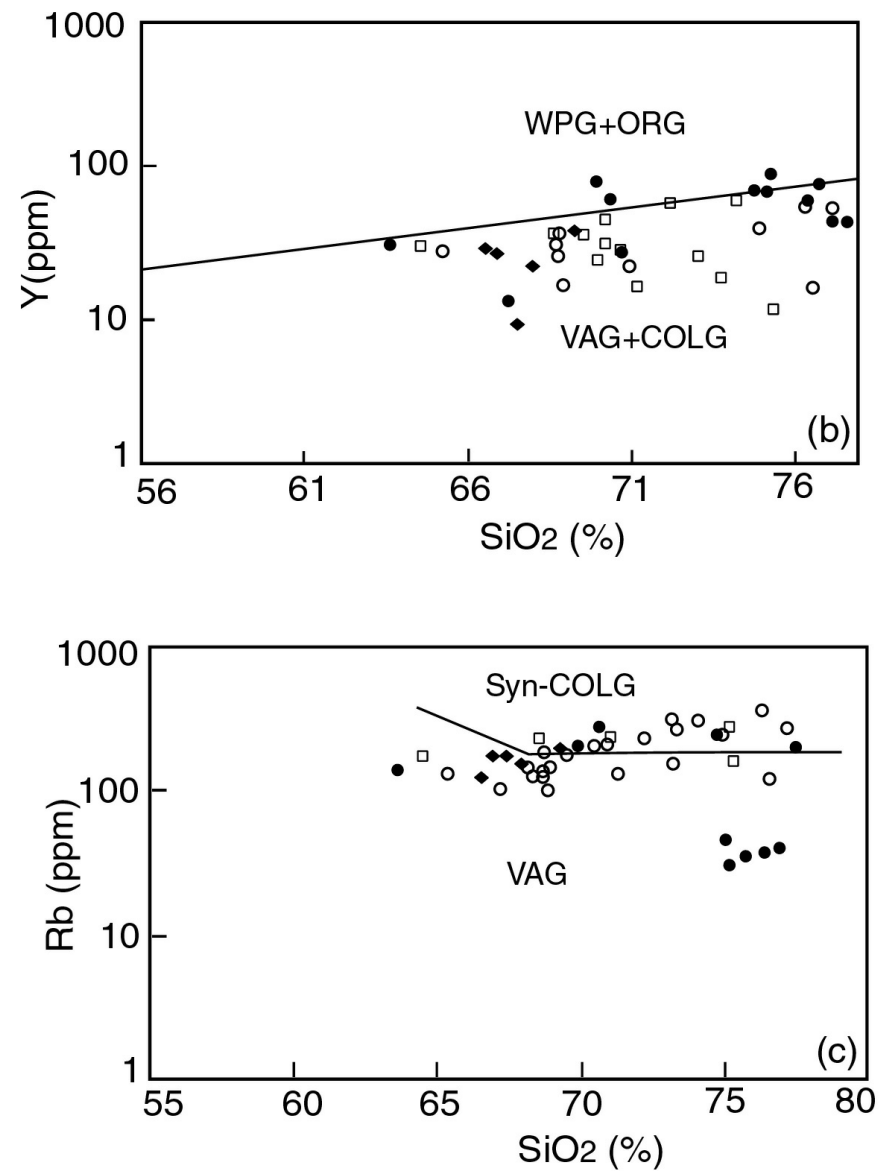
Petrogenetic and tectonic aspects of collisional granitoids from the Sanandaj-Sirjan Belt of Iran 97
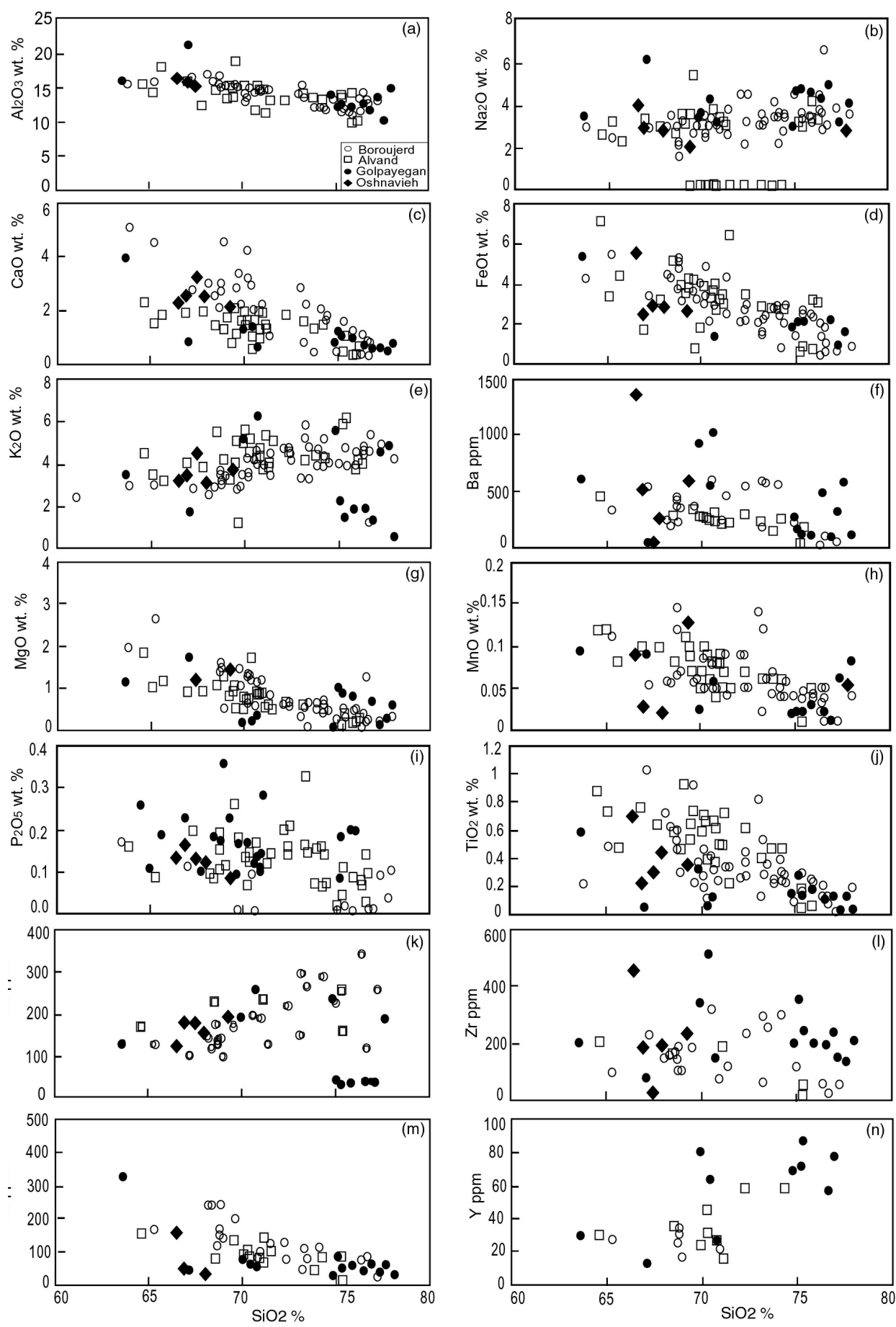

Fig. 10

Variation diagrams for the SSG. For more details see the text 


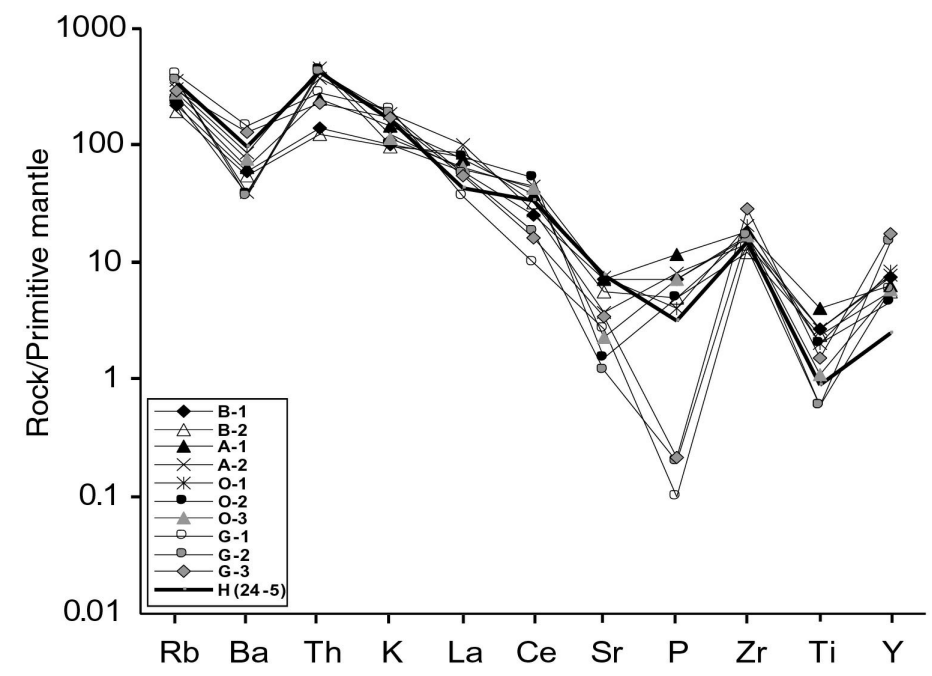

B: Boroujerd, A: Alvand, G: Golpayegan, O: Oshnavieh, H: Halatu

Fig. 11

Distribution patterns of trace incompatible elements normalized to primary mantle for the SSG. The normalization factors are from Sun and McDonough (1989)

\section{Petrogenesis and tectonic setting of SSG}

The SSG, of the petrographic composition of granite, granodiorite and tonalite, were generated from heterogeneous source materials by anatexis. The S-type granitoids were formed by partial melting of pelitic and felsic crustal rocks and Itype granitoids by partial melting of the lower crustal metabasic rocks (Chappell and White 1992).

The mineralogy of the SSG (e.g. aluminous minerals andalusite, sillimanite, garnet, muscovite), the existence of micaceous enclaves, the lack of extrusive equivalents, the lack of gabbros, the existence of normative corundum in most of the samples, the peraluminous nature of most of the samples, and the distribution pattern for REE and trace elements, all suggest that the SSG may be considered as products of partial melting of crustal materials.

In Figure 12 the source materials of SSG are shown using $\left(\mathrm{Na}_{2} \mathrm{O}+\mathrm{K}_{2} \mathrm{O}\right)$ / $\left.\mathrm{FeO}+\mathrm{MgO}+\mathrm{TiO}_{2}\right)$ and $\mathrm{CaO} /\left(\mathrm{FeO}+\mathrm{MgO}+\mathrm{TiO}_{2}\right)$ ratios (Patiño Douce 1996). The source materials are metagreywackes, amphibolites and felsic pelites. Also, molar $\mathrm{CaO} /(\mathrm{MgO}+\mathrm{FeOtotal})$ vs. molar $\mathrm{Al}_{2} \mathrm{O}_{3} /\left(\mathrm{MgO}+\mathrm{FeO}_{\text {total }}\right)$ indicates different sources as the original materials for generation of the SSG. Some samples plot in the partial melting from metagreywackes and metapelitic fields, while others show partial melting from metabasaltic to tonalitic source (Fig. 13), indicating heterogeneous sources for the SSG. 

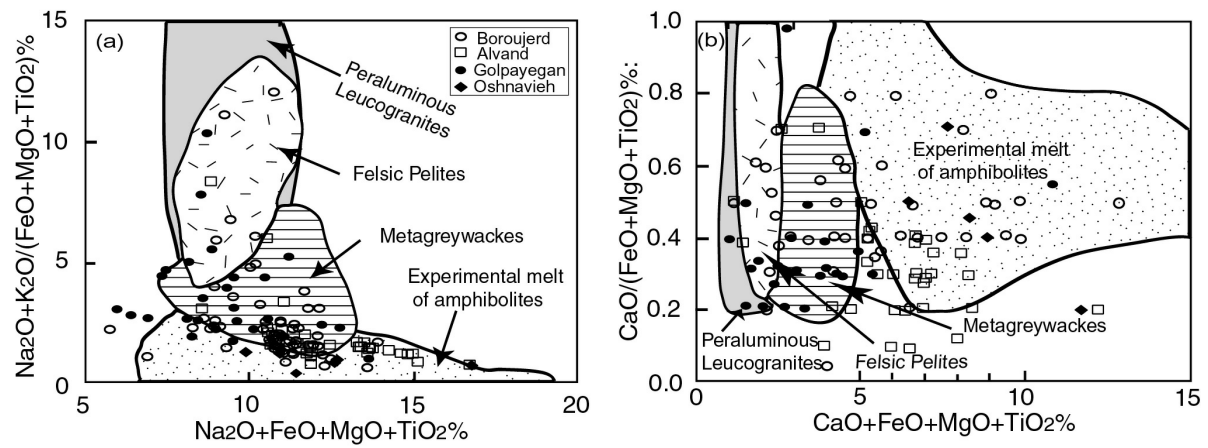

Fig. 12

The chemical composition of the SSG on the $\mathrm{Na}_{2} \mathrm{O}+\mathrm{K}_{2} \mathrm{O} /\left(\mathrm{FeO}+\mathrm{MgO}+\mathrm{TiO}_{2}\right)$ vs. $\left(\mathrm{Na}_{2} \mathrm{O}+\mathrm{FeO}\right.$ $\left.+\mathrm{MgO}+\mathrm{TiO}_{2}\right)$ and $\mathrm{CaO} /\left(\mathrm{FeO}+\mathrm{MgO}+\mathrm{TiO}_{2}\right)$ vs. $\left(\mathrm{CaO}+\mathrm{FeO}+\mathrm{MgO}+\mathrm{TiO}_{2}\right)$ diagrams from Patiño Douce (1996)

Fig. 13

Molar $\mathrm{Al}_{2} \mathrm{O}_{3} /\left(\mathrm{MgO}+\mathrm{FeO}_{\text {total }}\right)$ vs. molar $\mathrm{CaO} /\left(\mathrm{MgO}+\mathrm{FeO}_{\text {total }}\right)$ for the SSG. The fields on the diagram are the chemical composition of melts from experimental studies of dehydration melting of different source materials (Wolf and Wyllie 1994; Gardien et al. 1995; Patiño Douce and Beard 1995; Patiño Douce 1996; Patiño Douce and Beard 1996; Singh and Johannes 1996; Thompson 1996; Patiño Douce and McCarthy 1998, and references therein)

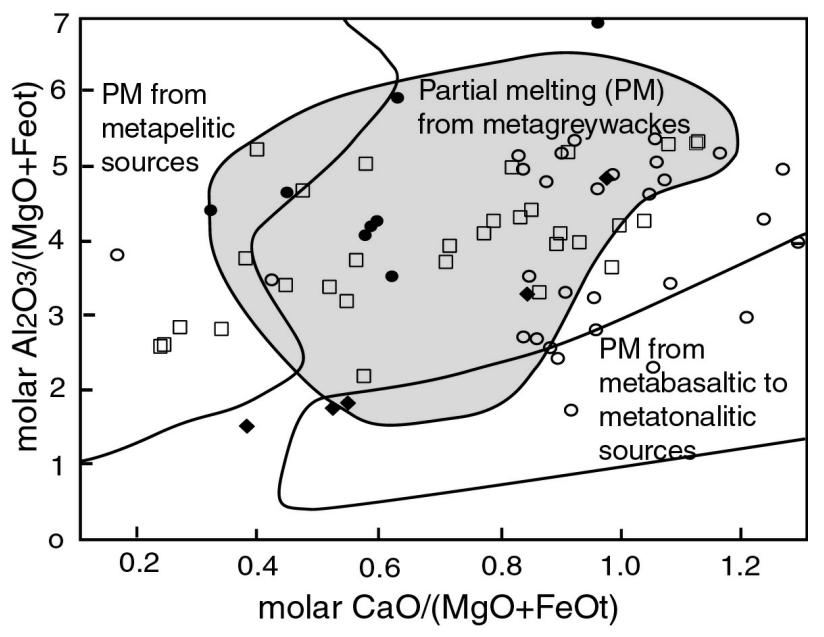

Although some Al-rich minerals can be crystallized from the anatectic melt, the existence of minerals such as sillimanite, cordierite and garnet with distinct metamorphic texture in SSG can suggest that the source materials (i.e. amphibolites, metagreywackes and pelites) were partially melted to form a silicic magma which in turn produced SSG. Based on mineral composition, the following melting reactions can be proposed for formation of these rocks (abbreviations are from Kretz 1983):

$$
\begin{array}{ll}
\mathrm{Bt}+\mathrm{Sil}+\mathrm{Qtz}+\mathrm{Pl}=\mathrm{Grt}+\mathrm{Crd}+\mathrm{Kfs}+\text { Melt } & \text { (for metapelitic and felsic rocks) } \\
\mathrm{Hbl}+\mathrm{Qtz}=\mathrm{Grt}+\mathrm{Cpx}+\mathrm{Opx}+\mathrm{Melt} & \text { (for Hbl-bearing mafic rocks) }
\end{array}
$$

Considering the experimental studies by Pattison et al. (2003), the minimum temperature for melting of pelitic and Hbl-bearing mafic rocks of the Sanandaj- 
Sirjan Zone could have been $\sim 700{ }^{\circ} \mathrm{C}$ and $780{ }^{\circ} \mathrm{C}$, respectively. Thermometry of the rocks based on $\mathrm{Zr}$ content vs. $(\mathrm{Na}+\mathrm{K}+2 \mathrm{Ca}) /\left(\mathrm{Al}{ }^{*} \mathrm{Si}\right)$ (Watson and Harrison 1983) shows temperatures of $700-850{ }^{\circ} \mathrm{C}$ for SSG rocks (Fig. 14). These temperatures are comparable with temperatures required for generation of granitic melt due to dehydration melting of continental crust at temperatures of ca. 750-850 ${ }^{\circ} \mathrm{C}$ (Wyborn et al. 1981; Wolf and Wyllie 1994; Rapp and Watson 1995; Patiño Douce and McCarthy 1998).

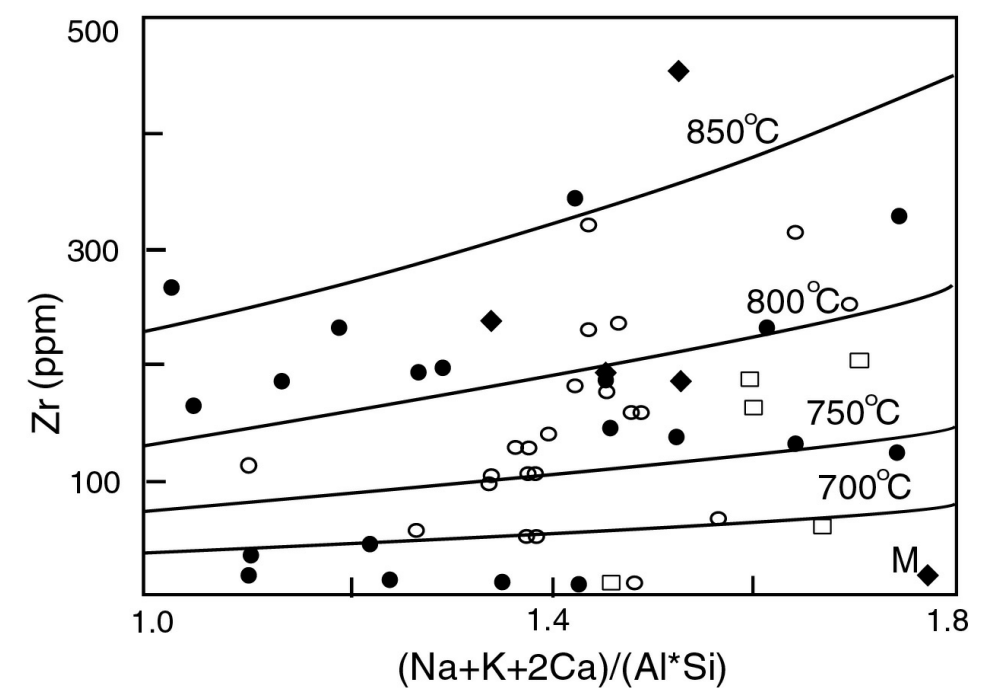

Fig. 14

Concentration of $\mathrm{Zr}$ in the SSG plotted against cationic percent of $(\mathrm{Na}+\mathrm{K}+2 \mathrm{Ca}) / \quad\left(\mathrm{Al}{ }^{*} \mathrm{Si}\right) \quad$ (Watson and Harrison, 1983). $700-850{ }^{\circ} \mathrm{C}$ isotherms show the $\mathrm{Zr}$ concentration in granitoid melts with different compositions

Considering the tectonic setting, discriminate diagrams, and all the abovementioned features, we conclude that the SSG formed in a continental collision setting. The scenario for formation of the SSG is as follows: The Neotethys Ocean (Zagros Ocean) in Iran, which was located between the Arabian Plate and the Central Iranian Block during the Paleozoic and Triassic, closed by subduction beneath the Central Iran Zone. Continental collision of the Arabian Plate and the Central Iranian Plate occurred during Cretaceous to Tertiary times. Intense deformation, metamorphism and intrusion of the plutonic rocks all are results of this collision. Arrangement of long axes of oval-shape granitoids along the main trend of the Zagros Orogen, elongated micaceous enclaves, and deformational textures and structures all support the formation of the SSG in a syn-collision environment. Differences in source materials were responsible for some differences in mineralogical and chemical compositions among the various rocks studied. 


\section{References}

Agard, P., J. Omrani, L. Jolivet, F. Mouthereau 2005: Convergence history across Zagros (Iran): Constraints from collisional and earlier deformation. - International Journal of Earth Sciences, 94, pp. 401-419.

Alavi, M. 1994: Tectonics of the Zagros orogenic belt of Iran: New data and interpretations. Tectonophysics, 229, pp. 211-238.

Berberian, M. 1977: Three phases of metamorphism in Haji-Abad quadrangle (southern extremity of the Sanandaj-Sirjan Zone), a palaeotectonic discussion. - In: Contribution of seismotectonics of Iran (Part III). - Geological Survey of Iran, 40, pp. 239-260.

Berberian, M., G.C.P. King 1981: Towards a paleogeography and tectonic evolution of Iran. Canadian Journal of Earth Science, 18, pp. 210-265.

Berberian F., I.D. Muir, R.J. Pankhurst, M. Berberian 1982: Late Cretaceous and early Miocene Andean-type plutonic activity in northern Makran and Central Iran. - Journal of Geological Society of London, 139, pp. 605-614.

Braud, J. 1987: La suture du Zagros au niveau de Kermanshah (Kurdistan iranien): Reconstitution palégéographique, évolution géodynamique, magmatique et structurale: - unpublished Ph.D. thesis, Université de Paris-Sud, 489 p.

Chappell, B.W.A., J.R. White 1992: I- and S-type granites in the Lachlan Fold Belt, Transactions of the Royal Society Edinburgh. - Earth Science, 83, pp. 1-26.

Chen, B., B.M. Jahn, S. Wilde, B. Xu 2000: Two contrasting Paleozoic magmatic belts in northern Inner Mongolia, China: petrogenesis and tectonic implications. - Tectonophysics, 328, pp. 157-182.

Farhoudi, G., D.E. Karig 1977: Makran of Iran and Pakistan as an Active Arc System. - Geology, 5, pp. 664-668.

Frost, B.R., G.G. Barnes, W.J. Collins, R.J. Arculus, D.J. Ellis, C.D. Frost 2001: A geochemical classification for granitic rocks. - Journal of Petrology, 42, pp. 2033-2048.

Gardien, V., A.B.Thompson, D. Grujic, P. Ulmer 1995: Experimental melting of biotite + plagioclase + quartz \pm muscovite assemblages and implications for crustal melting. Journal of Geophysics Research, 100, pp. 15581-15591.

Ghasemi, A., C. J. Talbot 2006: A new tectonic scenario for the Sanandaj-Sirjan Zone (Iran). - Journal of Asian Earth Sciences, 26, pp. 683-693.

Harris, N.B.W., J.A Pearce, A.G. Tindle 1986: Geochemical characteristics of collision-zone magmatism. - In: Coward, M.P., A.C. Ries (Eds): Collision Tectonics. Special Publications Geological Society of London, 19, pp. 67-81.

Harris, N.B.W., S. Inger 1992: Trace element modeling of pelite-derived granites. - Contribution to Mineralogy and Petrology, 110, pp. 46-56.

Irvine, T. N., W. R.A. Baragar 1971: A guide to the chemical classification of the common volcanic rocks. Canadian Journal of Earth Science, 8, pp. 523-548.

Isfahani, F, A. Sharifi 1999: Geochemical characteristics of magmatic rocks of Iran. - Geological Survey of Iran, 2, $1470 \mathrm{p}$. .

Jackson, D.D., K. Aki, C.A. Cornell, J.H. Dieterich, TL., Henyey, M. Mahdyiar, D. Schwartz, S.N. Ward 1995: Seismic hazards in southern California: Probable earthquakes, 1994-2024. - Bulletin of the Seismological Society of America, 85, pp. 379-439.

James, R.S., D.L. Hamilton 1969: Phase relations in the system albite \pm orthoclase \pm anorthite \pm quartz at $1 \mathrm{~kb}$ water vapor pressure. - Contribution to Mineralogy and Petrology, 21, pp. 111-141.

Kretz, R. 1983: Symbols for rock forming minerals. - American Mineralogist, 68, pp. 277-279.

LeMaitre, R.W. 1976: Some problems of the projection of chemical data into mineralogist Classification. - Contribution to Mineralogy and Petrology, 56, pp. 181-189.

McCall, G.J.H. 1997: The geotectonic history of the Makran and adjacent areas of southern Iran. Journal of Asian Earth Science, 15, pp. 517-531. 
Middlemost, E.A.K. 1994: Naming material in the magma/igneous rock system. - Earth Science Reviews, 37, pp. 215-224.

Miyashiro, A. 1978: Nature of alkalic volcanic rock series. - Contribution to Mineralogy and Petrology, 66, pp. 91-104.

Moazzen, M., M. Moayyed, E. Darvishi 2002: Syn-collision, S-type granitoids of NE Azna, Western Iran. - 18th general meeting of the IMA 1-6 Sep. Edinburgh, Programme with Abstract, pp. 261-262.

Moazzen, M., M. Moayyed, M. Modjarrad, E. Darvishi 2004: Azna granitoid as an example of syncollision S-type granitisation in Sanandaj-Sirjan metamorphic belt, Iran. - Neues Jahrbuch für Mineralogie Monatshefte, 11, pp. 489-507.

Mohajjel, M., C.L. Fergusson, M.R. Sahandi 2003: Cretaceous-Tertiary convergence and continental collision, Sanandaj-Sirjan Zone, western Iran. - Journal of Asian Earth Science, 21, pp. 397-412.

O'Connor, J.T. 1965: A classification for Quartz-rich igneous rocks based on Feldspar ratios. - US Geological Survey Professional Papers, 525B, pp. 79-84.

Patiño Douce, A.E., J.S. Beard 1995: Dehydration melting of biotite gneiss and quartz-amphibolite from 3 to 15 kbar. - Journal of Petrology, 36, pp. 707-738.

Patiño Douce, A.E. 1996: Effects of pressure and $\mathrm{H}_{2} \mathrm{O}$ content on the compositions of primary crustal melt. - Transactions of the Royal Society of Edinburgh: Earth Science, 87, pp. 11-21.

Patiño Douce, A.E., J.S. Beard 1996: Effects of $\mathrm{P} \mathrm{f}(\mathrm{O} 2)$ and $\mathrm{Mg} / \mathrm{Fe}$ ratio on dehydration melting of model metagreywackes. - Journal of Petrology, 37, pp. 999-1024.

Patiño Douce, A.E., T.C. McCarthy 1998: Melting of crustal rocks during continental collision and subduction. - In: B.R. Hacker, J.G. Liou (Eds): When continents collide. - Dordrecht, Netherlands, Kluwer Academic, pp. 27-55.

Pattison, D.R.M., T. Chacko, J. Farquhar, C.R.M. McFarlane 2003: Temperatures of granulite-facies metamorphism: Constraints from experimental phase equilibria and thermobarometry corrected for retrograde exchange. - Journal of Petrology, 44, pp. 867-900.

Pearce, J.A., N.B.W. Harris, A.G. Tindle 1984: Trace element discrimination diagrams for the tectonic interpretation of granitic rocks. - Journal of Petrology, 25, pp. 956-983.

Peccerillo, R., S.R. Taylor 1976: Geochemistry of Eocene calc-alkaline rocks from Kastamonu area, Northern Turkey. - Contribution to Mineralogy and Petrology, 58, pp. 63-81.

Rapp, R.P., E.B. Watson 1995: Dehydration melting of metabasalt at 8-32 kbar; implications for continental growth and crust-mantle recycling. - Journal of Petrology, 36, pp. 891-931.

Rickwood, P.C. 1989: Boundary lines within petrologic diagrams, which use oxides of major and minor elements. - Lithos, 22, pp. 247-263.

Sabzehi, M. 1992: Geological map of Hajiabad area, 1:250000. - Geological Survey of Iran.

Sengör, A.M.C., D. Altiner, A. Cin, T. Ustaomer, K.J. Hsu 1988: Origin and assembly of the Tethyside orogenic collage at the expense of Gondwana Land. - Geological of Society of London, Special Publication, 37, pp. 119-181.

Sengör, A.M.C., B.A. Natal'in, V.S. Burtman 1993: Evolution of the Altaid tectonic collage and Palaeozoic crustal growth in Eurasia. - Nature, 364, pp. 299-307.

Sengör, A.M.C., B.A. Nataln'in 1996: Paleotectonics of Asia: Fragments of a synthesis. - In: Yin, A., T. M. Harrison (Eds): The Tectonic Evolution of Asia. - Cambridge University Press, pp. 486-640.

Sun, S.S., W.F. McDonough 1989: Chemical and isotopic systematic of oceanic basalts: implications for mantle composition and processes. - In: Saunders, A.D., M.J. Norry (Eds): Magmatism in the Ocean Basins. - Geological Society of London Special Publication, 42, pp. 313-345.

Wang, D.Z., L.Sh. Zhu, M. Faure,W.Z. Sheng 2001: Mesozoic magmatism and granitic dome in the Wugongshan Massif, Jiangxi province and their genetical relationship to the tectonic events in southeast China. - Tectonophysics, 339, pp. 259-277.

Watson, E.B., T. M. Harrison 1983: Zircon Saturation revisited: temperature and composition effects in a variety of crustal magma types. - Earth Planetary Science Letters, 64, pp. 295-304.

Wolf, M.B., P.J. Wyllie 1994: Dehydration-melting of amphibolite at 10 kbar: the effects of temperature and time. - Contribution to Mineralogy and Petrology, 115, pp. 369-383.

Wyborn, D., B.W. Chappell, R.M. Johnston 1981: Three S-type volcanic suites from the Lachlan Fold Belt, southeast Australia. - Journal of Geophysics Research, 86, pp. 10335-10348.

Central European Geology 55, 2012 